\title{
New and interesting Surirella taxa (Surirellaceae, Bacillariophyta) from the Congo Basin (DR Congo)
}

\author{
Christine COCQUYT ${ }^{1} \&$ Jonathan C. TAYLOR ${ }^{2}$ \\ ${ }^{1,2}$ Botanic Garden Meise, Domein van Bouchout, B-1860 Meise, Belgium. \\ ${ }^{1}$ Email: christine.cocquyt@br.fgov.be (corresponding author) \\ ${ }^{2}$ School of Biological Sciences, North-West University, Potchefstroom, South Africa. \\ ${ }^{2}$ South African Institute for Aquatic Biodiversity, Grahamstown, South Africa.
}

\begin{abstract}
Two new diatom taxa belonging to the genus Surirella, S. ebalensis and S. congolensis, are described from material of the Congo Basin, downstream Kisangani, DR Congo. The first taxon is a small, rather common species in the studied material; the second a somewhat larger diatom that was only sporadically observed. The morphology of both taxa is examined with light and scanning electron microscopy. The differences between the new and other closely related taxa such as $S$. agonaensis and S. bonsaensis, and S. takoradiensis, S. tenuissima and S. pseudotenuissima, respectively, are discussed.
\end{abstract}

Keywords. Africa, diatoms, new species, Surirella.

Cocquyt C. \& Taylor J.C. 2015. New and interesting Surirella taxa (Surirellaceae, Bacillariophyta) from the Congo Basin (DR Congo). European Journal of Taxonomy 133: 1-15. http://dx.doi.org/10.5852/ejt.2015.133

\section{Introduction}

Algal reports from for the Democratic Republic of the Congo (DR Congo), formerly Belgian Congo and Zaire, are very limited (e.g., Duvigneaud \& Symoens 1949; Hustedt in Huber-Pestalozzi 1949; Kufferath 1956a, b; Compère \& Symoens 1987, 1988; Compère et al. 1989; Golama Swana Kaketa 1992, 1996 and Compère 1995). During the Belgian-Congolese Boyekoli Ebale Congo 2010 Expedition, covering $250 \mathrm{~km}$ of the Congo River and some of its tributaries between Kisangani and Bumba (see Nagy et al. 2011; Virgilio et al. 2011), samples for diatom studies were taken in an unexplored, from an algal point of view, part of the Congo Basin. Some extra samples were taken in this region during two smaller expeditions in the frame of the COBAFISH project. In the sampled area, where people from rural villages live predominantly from subsistence-based agriculture (closely associated with rivers) and fisheries, pristine habitats are rather scarce. The area is characterized by many oil palm and rubber plantations, coffee, cacao, and tea and cotton cultivation, generally farmed by smallholders. The nearest area from where results on diatom studies have been reported in the past is close to Kisangani (Golama Swana Kaketa 1992, 1996; Compère 1995).

From samples taken during the aforementioned Boyekoli Ebale Congo 2010 Expedition, a new diatom, Cavinula lilandae Cocquyt, M. de Haan \& J.C. Taylor was recently described (Cocquyt et al. 2013). The present paper deals with the description of two other new taxa, both belonging to the genus Surirella Turpin. The first taxon is a small, rather common species in the studied material sampled in the Congo Basin during the 2010 expedition and during two smaller expeditions in November 2012 and September 2013. The second taxon is a somewhat larger diatom that was only sporadically observed in the studied material. 


\section{Material and methods}

Material from the Congo Basin, downstream of Kisangani, was collected in May 2010 during the Boyekoli Ebale Congo 2010 Expedition. Supplementary samples were taken in November 2012 and September 2013 on two smaller expeditions in the frame of the COBAFISH project. For the description of the new taxa discussed in the present paper the following samples were examined:

- CCA 2070: Lomami River, $0.49339^{\circ} \mathrm{N}$ and $24.16960^{\circ} \mathrm{E}$, epiphytic on Nymphaea lotus Linnaeus; collected by François Darchambeau and Ernest Tambwe on 24 Nov. 2012; temperature $25.7^{\circ} \mathrm{C}$, pH 6.06, conductivity $22.2 \mu \mathrm{S} \mathrm{cm}^{-1}, 0.060 \mathrm{mg} \mathrm{l}^{-1} \mathrm{NH}_{4}, 0.005 \mathrm{mg} \mathrm{l}^{-1} \mathrm{NO}_{2}, 0.446 \mathrm{mg} \mathrm{l}^{-1} \mathrm{NO}_{3}, 0.086 \mathrm{mg} \mathrm{l}^{-1}$ soluble reactive phosphorous (SRP).

- CCA 2071: Lomami River, $0.49339^{\circ} \mathrm{N}$ and $24.16960^{\circ} \mathrm{E}$, epiphyton on dead submerged wood; collected by François Darchambeau and Ernest Tambwe on 24 Nov. 2012; temperature $25.7^{\circ} \mathrm{C}$, pH 6.06, conductivity $22.2 \mu \mathrm{S} \mathrm{cm}^{-1}, 0.060 \mathrm{mg} \mathrm{l}^{-1} \mathrm{NH}_{4}, 0005 \mathrm{mg} \mathrm{l}^{-1} \mathrm{NO}_{2}, 0.446 \mathrm{mg} \mathrm{l}^{-1} \mathrm{NO}_{3}, 0.086 \mathrm{mg} \mathrm{l}^{-1}$ soluble reactive phosphorous (SRP).

In contrast to the samples from the Boyekoli Ebale Congo 2010 Expedition which were fixed in situ with $30 \%$ formalin, the samples collected on later expeditions in 2012 and 2013 were preserved in ethanol $(20 \%$ vv.). Part of these samples were oxidized with hydrogen peroxide $(30 \%)$, rinsed five times with distilled water and embedded in Naphrax ${ }^{\circledR}$ mounting medium. Light microscopic (LM) investigations were carried out with an oil immersion objective $(100 \times)$ using an Olympus BX 51 microscope, equipped with Nomarski differential interference contrast optics (DIC) and an Olympus UC30 digital camera. For scanning electron microscopy (SEM) aliquots of the oxidized material were filtered through $0.3 \mu \mathrm{m}$ Millipore ${ }^{\circledR}$ filters and then in turn fixed to aluminum stubs, air-dried and sputter-coated with $50 \mathrm{~nm}$ of gold. SEM studied were carried out both at the Botanic Garden Meise (Belgium) and the NorthWest University (South Africa) with a JEOL-5800LV operating at $25 \mathrm{kV}$ and an FEI Quanta 2000 field emission scanning electron operating at $10 \mathrm{kV}$ respectively.

The raw and the cleaned samples and the permanent slides for diatom investigation are housed at the herbarium of the Botanic Garden Meise (BR). A copy of each permanent slide will be deposited at the Centre de Surveillance de la Biodiversité (CSB) or at the Herbarium of the University of Kisangani, DR Congo.

Water temperature, conductivity and $\mathrm{pH}$ were measured using an YSI ProPlus multiprobe field meter equipped with a $\mathrm{pH}$ sensor 1001 ProSeries. Samples for nutrient analyses $\left(\mathrm{NH}_{4}, \mathrm{NO}_{3}, \mathrm{NO}_{2}\right.$ and SRP) were filtered and acidified in situ, and kept frozen until spectrophotometric analysis in the laboratory of the Unité d'Océanographie Chimique, Département d'Astrophysique, Géophysique et Océanographie, University of Liège, Belgium.

\section{Results}

Class Bacillariophyceae Haeckel emend. Medlin \& Kaczmarska (Medlin \& Kaczmarska 2004) Subclass Bacillariophycidae D.G. Mann in Round et al. (Round et al. 1990)

Order Surirellales D. G. Mann in Round et al. (Round et al. 1990)

Family Surirellaceae Kützing (Kützing 1844)

Genus Surirella Turpin (Turpin 1828)

Surirella ebalensis Cocquyt \& J.C. Taylor sp. nov.

Figs $1-5$

\section{Diagnosis}

Valves slightly heteropolar, broadly linear to slightly cuneate with broadly rounded poles and slightly constricted margins in the larger valves, smaller valves not constricted. Apical pole broader than base 
pole. Length: 39.4-64.5 $\mu \mathrm{m}$; width: 16.1-19.4 $\mu \mathrm{m}$, in the constricted part $18.7 \mu \mathrm{m}$. Wing projection very distinct, alar canals smaller than fenestrae, 2.2-3.0 in $10 \mu \mathrm{m}$. Fenestral bars distinct in LM, 30 in $10 \mu \mathrm{m}$. Striae indistinct in LM, 30 in $10 \mu \mathrm{m}$. Valve face covered with numerous silica granules and spines. Spines also present on the keel. Porcae perpendicular to the axial axis, reaching the axial area and becoming radiate near the poles.
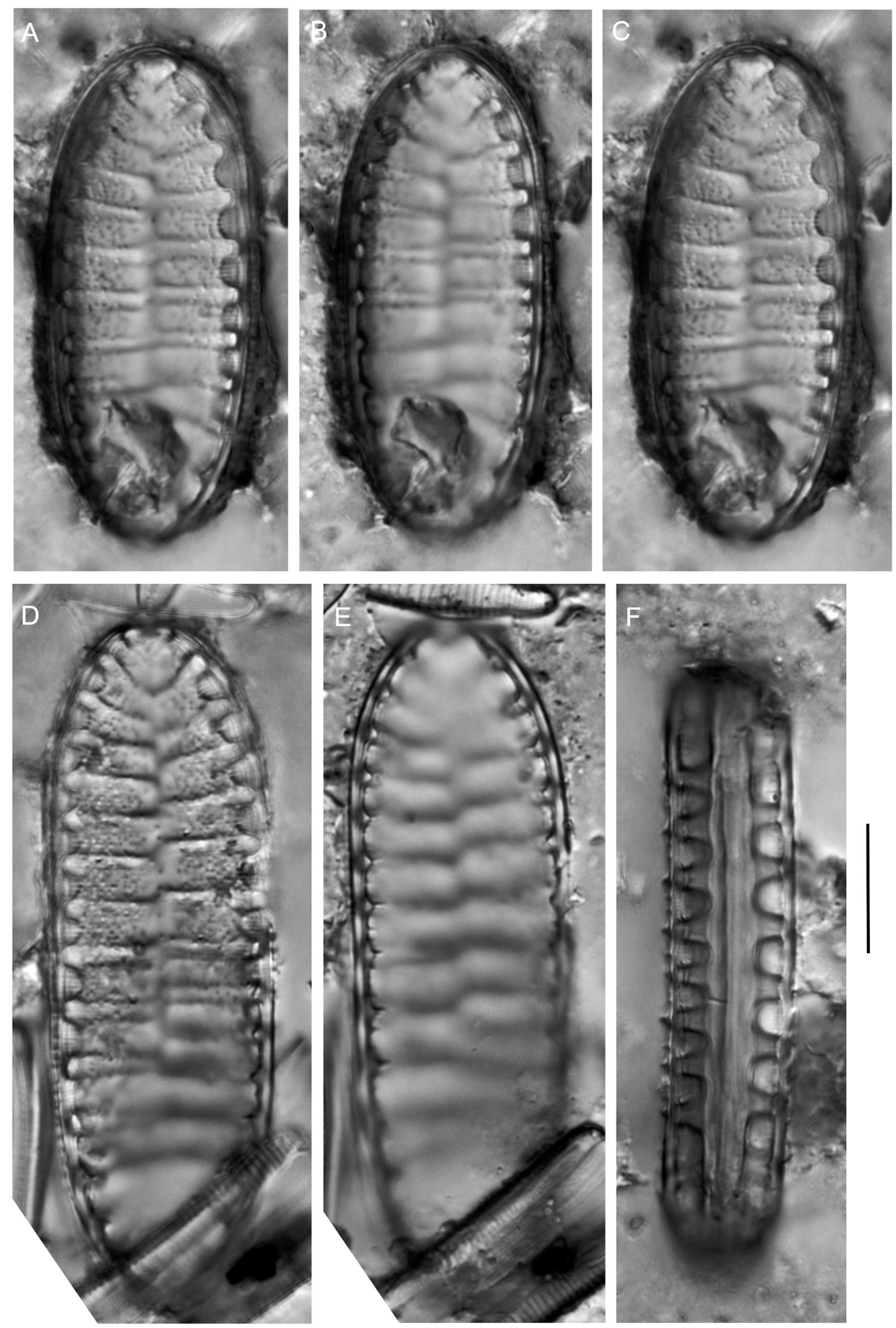

Fig. 1. Surirella ebalensis sp. nov., from the holotype slide BR 4398, Lomami River, DR Congo, LM (DIC). A-C. Valve representing the holotype, different foci of the same valve. D-E. Different foci of the same valve. F. Girdle view. Scale bar $=10 \mu \mathrm{m}$. 

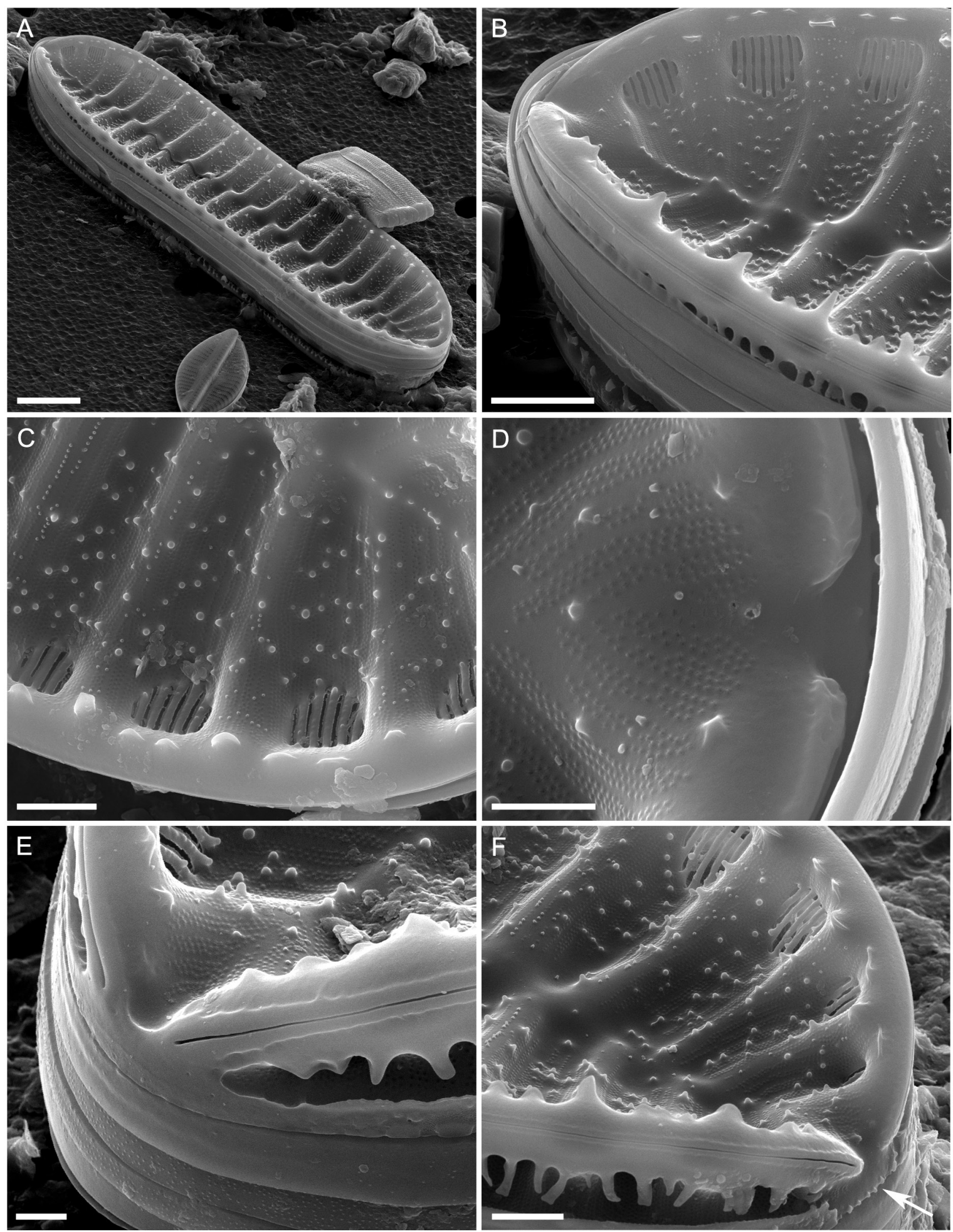

Fig. 2. Surirella ebalensis sp. nov., type material from sample CCA 2070, Lomami River, DR Congo, SEM. External view. B, C, F = detail of the raphe keel with blunt spines orientated towards the valve face and which are draped over a large part of the indented mantle side. A. Overview. B-C. Detail of the valve ornamented with silica granules and blunt spines. D. Detail of the apical pole, showing the curved raphe endings. E-F. Detail of the foot pole showing the straight raphe endings. F. Short spherical shaped silica elements near the pole (arrow). Scale bars: $\mathrm{A}=10 \mu \mathrm{m} ; \mathrm{B}=4 \mu \mathrm{m} ; \mathrm{C}, \mathrm{F}=2 \mu \mathrm{m} ; \mathrm{D}-\mathrm{E}=1 \mu \mathrm{m}$. 


\section{Etymology}

The specific epithet refers to the Lingala word for river which was used in the naming of the expedition, Boyekoli Ebale Congo 2010 (the Study of the Congo River 2010), during which numerous algal samples were collected.

\section{Type material}

\section{Holotype}

Slide BR 4398 from sample CCA 2070, Botanic Garden Meise, Belgium (BR). The valve representing the holotype is here illustrated in Fig. 1A.

\section{Isotype}

Slide Zu10/18 from sample CCA 2070, the Friedrich Hustedt Diatom Collection, Alfred-WegenerInstitut für Polar- und Meeresforschung, Bremerhaven, Germany (BRM).
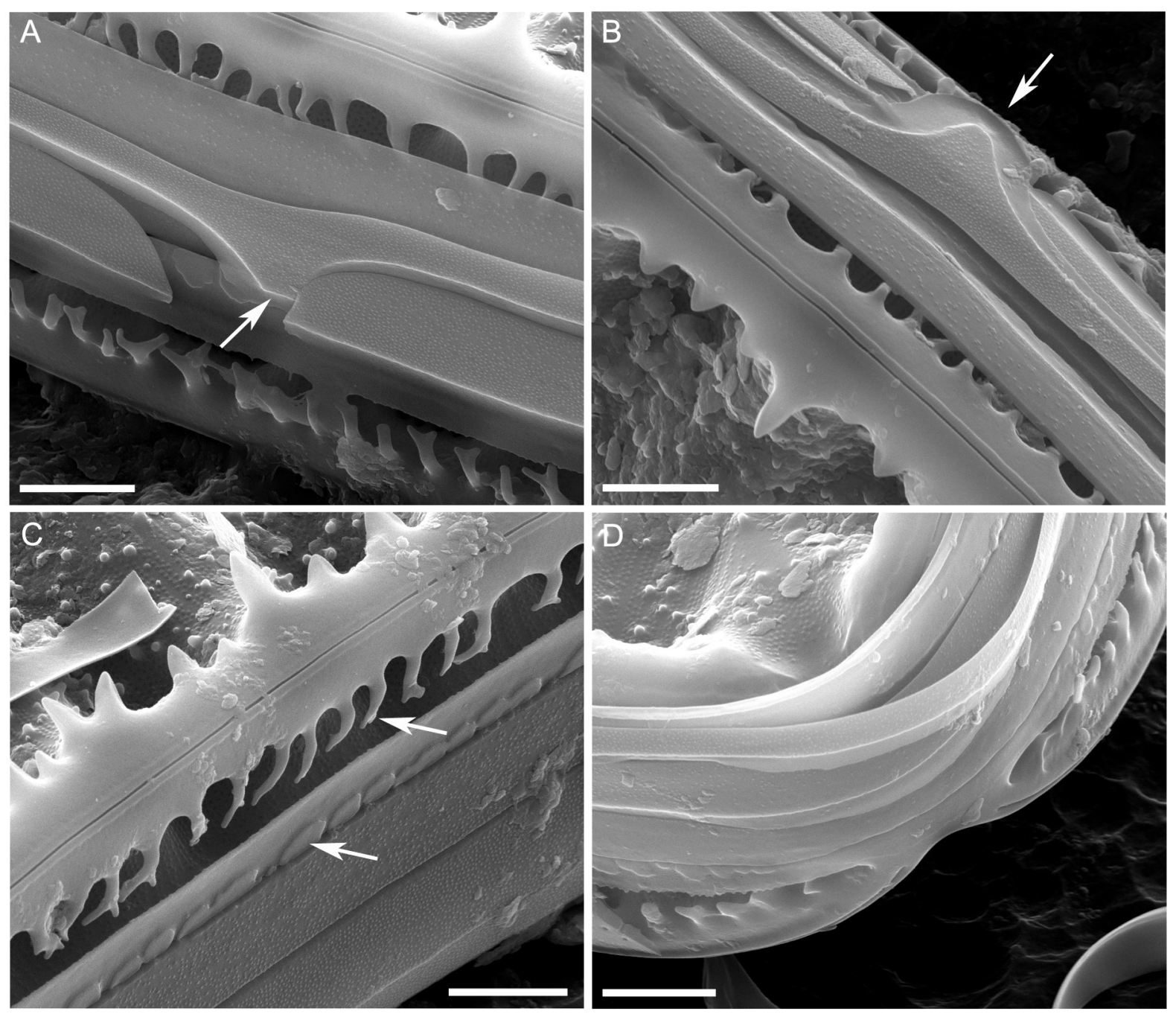

Fig. 3. Surirella ebalensis sp. nov., type material from sample CCA 2070, Lomami River, DR Congo, SEM. External view. A-B. Detail of the girdle showing a part of a girdle with ligula (arrow) and the neighbouring interrupted band. C. Detail of the valve mantle with the draped silica spines (arrow) and the silica plaques (arrow) near the edge of the mantle and the valvocopula. D. Detail of the girdle band near the pole. Scale bars $=2 \mu \mathrm{m}$. 


\section{Type locality}

Oriental Province, DR Congo, Lomami River $\left(0.49339^{\circ} \mathrm{N}\right.$ and $\left.24.16960^{\circ} \mathrm{E}\right)$. Epiphyton on Nymphaea lotus; collected by François Darchambeau and Ernest Tambwe on 24 Nov. 2012.

\section{Morphological observations using scanning electron microscopy (Figs 2-5)}

Axial area narrow to absent near the poles. In the middle of the valve the axial area becomes broader and then larger in the depressions than on the top of the porcae (transapical valve undulations). Porcae perpendicular to the axial axis, becoming radiate near the poles and reaching the axial area but not in the extension of each other near the axial area. Striae biseriate, seldom with uniseriate parts near the axial area (Figs 2C, 4B), about 30 in $10 \mu \mathrm{m}$. Near the fenestrae the striae often become triseriate, sometimes quadriseriate (Fig. 2D), and also present for a short distance on the raphe canal just above the fenestrae. Striae composed of 80-110 areolae in $10 \mu \mathrm{m}$. Numerous blunt spines scattered over the valve face
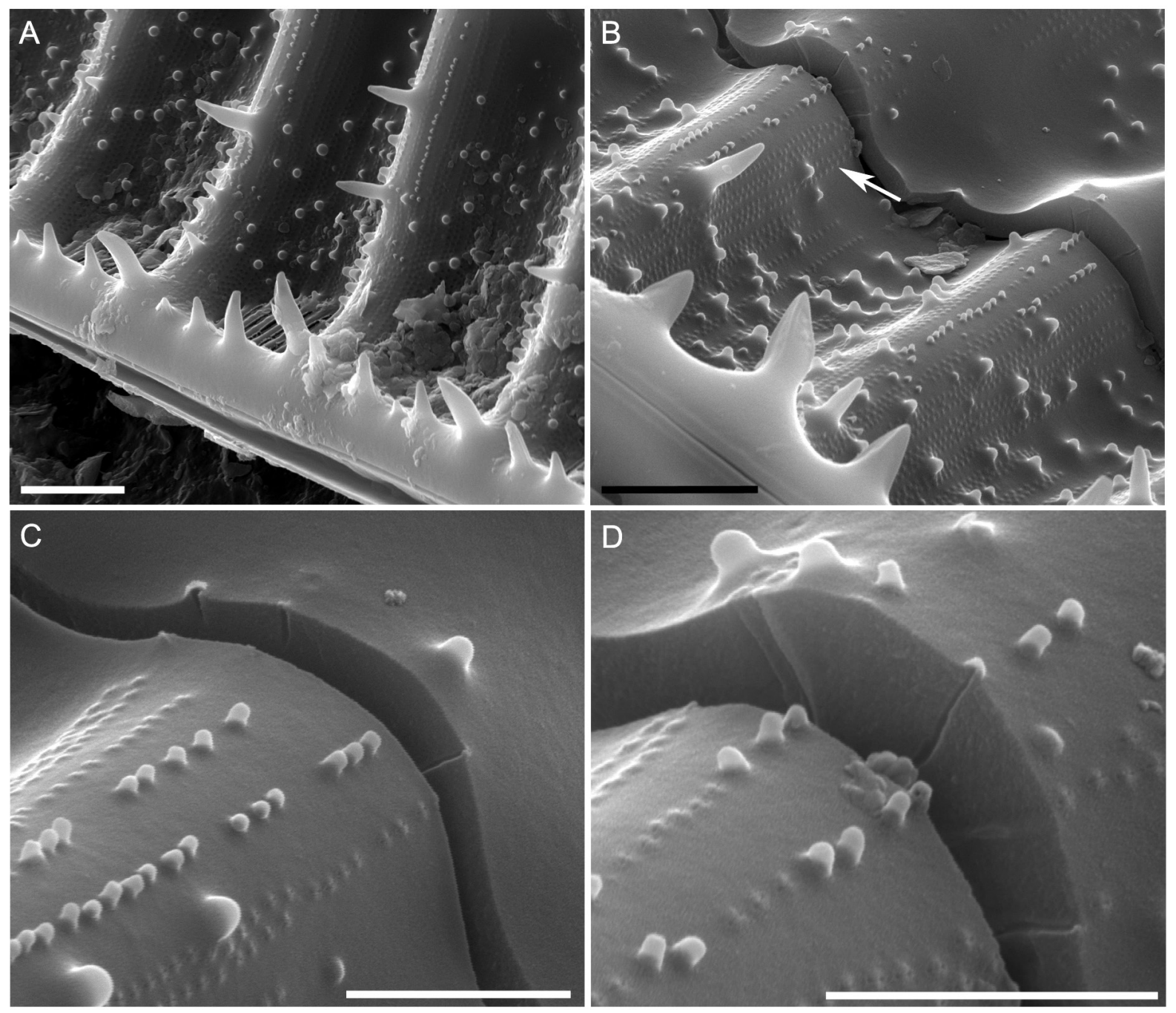

Fig. 4. Surirella ebalensis sp. nov., type material from sample CCA 2070, Lomami River, DR Congo, SEM. External view. Details of the various types of spines on the valve face and the keel. A-B. Detail of the valve surface with the biseriate striae (arrow) becoming sometimes uniseriate near the axial area. C-D. Section of the valve face showing the simple perforation of the silica wall at the areolae. Scale bars: $\mathrm{A}-\mathrm{B}=2 \mu \mathrm{m} ; \mathrm{C}-\mathrm{D}=1 \mu \mathrm{m}$. 
(Fig. 2B-F). On the top of the porcae these spines can become large, up to $1 \mu \mathrm{m}$ (Fig. 4A-B). In the depressions the spines look more like elongated granules. Another kind of ornamentation is also present on the valve face: small granules located on the striae, composed of an areola that seems to secrete silica on the outside of the valve face (Fig. 4C-D). Sometimes all areolae of almost the entire stria have these granules on the valve face. On the inside the elongated granules are characterized by a perforation of the wall (Fig. 4D) that has no rimmed margins as the normal areolae do (Fig. 5A). Blunt spines are also present on the keel; the spines orientated towards the valve face are of different length and arranged on a single transapical row (Fig. 2B). These spines are often transapically elongated near their base, the shorter ones more triangular in shape (Fig. 4B). On the side towards the mantle the spines on the keel are often bifurcated; they are draped over a large part of the indented mantle side, partially covering the fenestrae (Fig. 3C). The mantle face near the edge of the mantle at the junction with the valvocopula is smooth and bears a single row of small areolae and oval silica plaques (Fig. 3C). At the apical pole these silica plaques are replaced by around 10 short spherical shaped silica elements (Fig. 2F). Bi- to triseriate
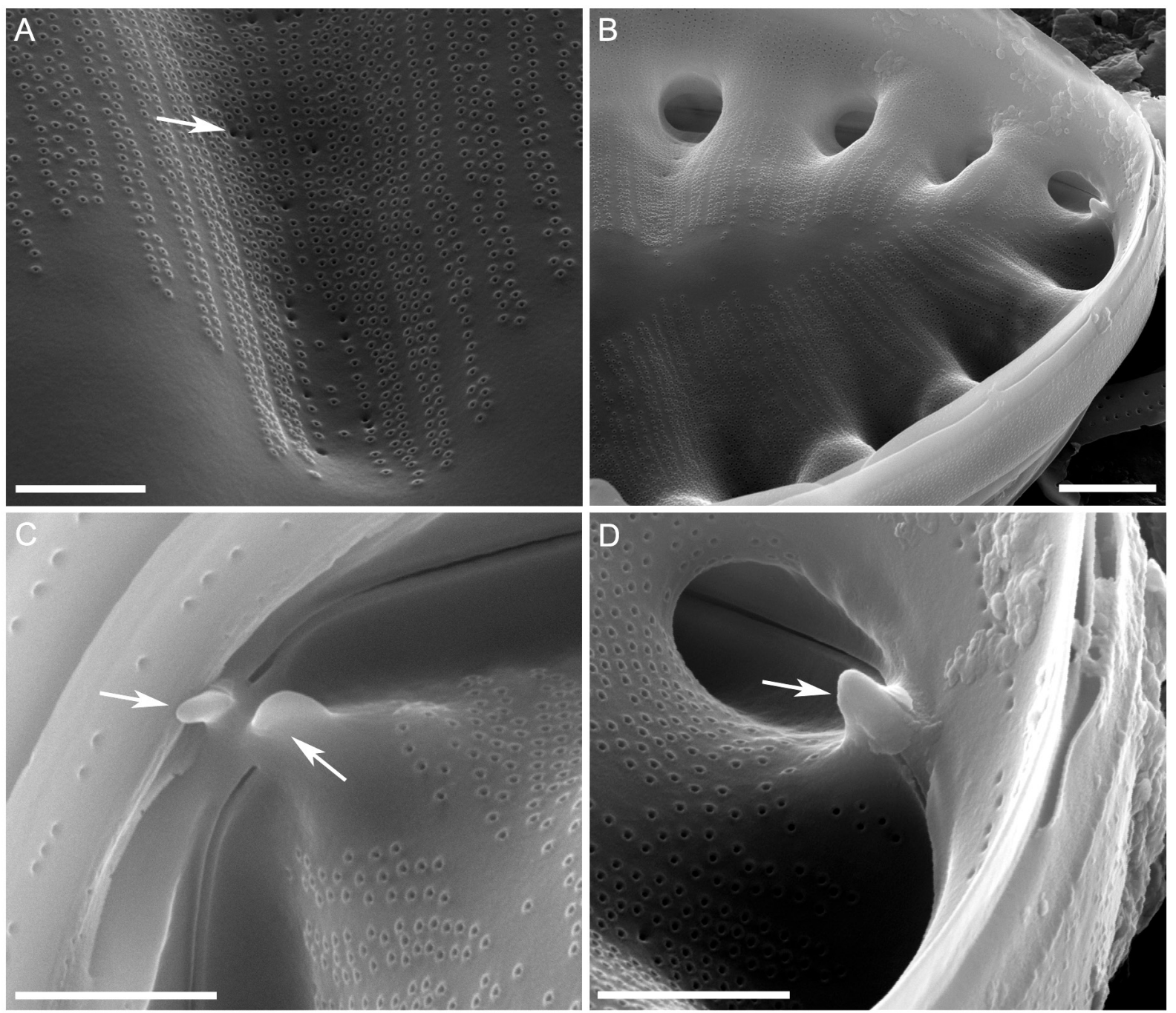

Fig. 5. Surirella ebalensis sp. nov., type material from sample CCA 2070, Lomami River, DR Congo, SEM. Internal view. A. Detail of the multiseriate striae, and the perforation of the elongated granules without rimmed margin (arrow). B, D. Detail of the continuous raphe near the apical pole with a reduced helictoglossa (arrow). C. Detail of the straight not expanded raphe endings at the foot pole and their reduced helictoglossae (arrows). Scale bars: $\mathrm{B}=2 \mu \mathrm{m} ; \mathrm{A}, \mathrm{C}-\mathrm{D}=1 \mu \mathrm{m}$. 
striae are present on the indented mantle face at the level of the fenestrae bars. Fenestrae are broader than the alar canals; 30 fenestral bars in $10 \mu \mathrm{m}$. External raphe endings are straight, not enlarged at both poles. Internally the raphe is continuous at the head pole while at the base pole the raphe slit is internally interrupted at different levels. Both slits end in a structure resembling a reduced helictoglossa, lacking the typical lip-like structure, and located farther away from the raphe ending (Fig. 5B-D). The girdle is composed of two bands. The open valvocopula band is not smooth but bears tiny granules (Fig. 3C); the second band with a broad ligula and the same tiny ornamentation except on the part of the ligula that is covered by the valvocopula (Fig. 3A-B).

\section{Ecology}

Physical and chemical parameters measured at the type locality are as follows: temperature $25.7^{\circ} \mathrm{C}$, pH 6.06, conductivity $22.2 \mu \mathrm{S} \mathrm{cm}^{-1}, 0.060 \mathrm{mg} \mathrm{l}^{-1} \mathrm{NH}_{4}, 0.005 \mathrm{mg} \mathrm{l}^{-1} \mathrm{NO}_{2}, 0.446 \mathrm{mg} \mathrm{l}^{-1} \mathrm{NO}_{3}, 0.086 \mathrm{mg} \mathrm{l}^{-1}$ soluble reactive phosphorous (SRP).

Surirella ebalensis sp. nov. was observed in a diatom community dominated by Eunotia bidens Ehrenberg, Frustulia cf. saxonica Rabenhorst, Pinnularia acrosphaeria W. Smith, Luticola muticoides (Hustedt) D.G. Mann, Encyonema minutum (Hilse) D.G. Mann, Stenopterobia anceps (Lewis) Brébisson, Eunotia spp., Cymbopleura sp., Placoneis sp., Caloneis sp. and Neidium sp.

Surirella congolensis Cocquyt \& J.C. Taylor sp. nov.

Figs 6-9

\section{Diagnosis}

Valves heteropolar, lanceolate with broadly rounded apical pole and subacute base pole, becoming gradually narrower from the apical pole to the base pole; larger valves slightly constricted mid-valve. Valve length 18.7-33.0, width (4.2) 5.5-6.9 (7.9) $\mu \mathrm{m}$. Wing projection distinct. Alar canals short, not reaching the axial area, 5.5-6.0 in $10 \mu \mathrm{m}$, much smaller than the fenestrae, and rarely becoming denser near the poles. Striae about 30 in $10 \mu \mathrm{m}$.

\section{Etymology}

The specific epithet refers to the Congo River and the Democratic Republic of the Congo where the samples were collected.

\section{Type material}

\section{Holotype}

Slide BR 4399 from sample CCA 2071, Botanic Garden Meise, Belgium (BR). The valve representing the holotype is here illustrated in Fig. 6G.

\section{Isotype}

Slide Zu10/19 from sample CCA 2071, the Friedrich Hustedt Diatom Collection, Alfred-WegenerInstitut für Polar- und Meeresforschung, Bremerhaven, Germany (BRM).

CCA 2071: Lomami River, $0.49339^{\circ} \mathrm{N}$ and $24.16960^{\circ} \mathrm{E}$, epiphyton on dead submerged wood, collected by François Darchambeau and Ernest Tambwe on 24 Nov. 2012.

\section{Type locality}

Oriental Province, DR Congo, Lomami River $\left(0.49339^{\circ} \mathrm{N}\right.$ and $\left.24.16960^{\circ} \mathrm{E}\right)$. Epiphyton on dead submerged wood. 

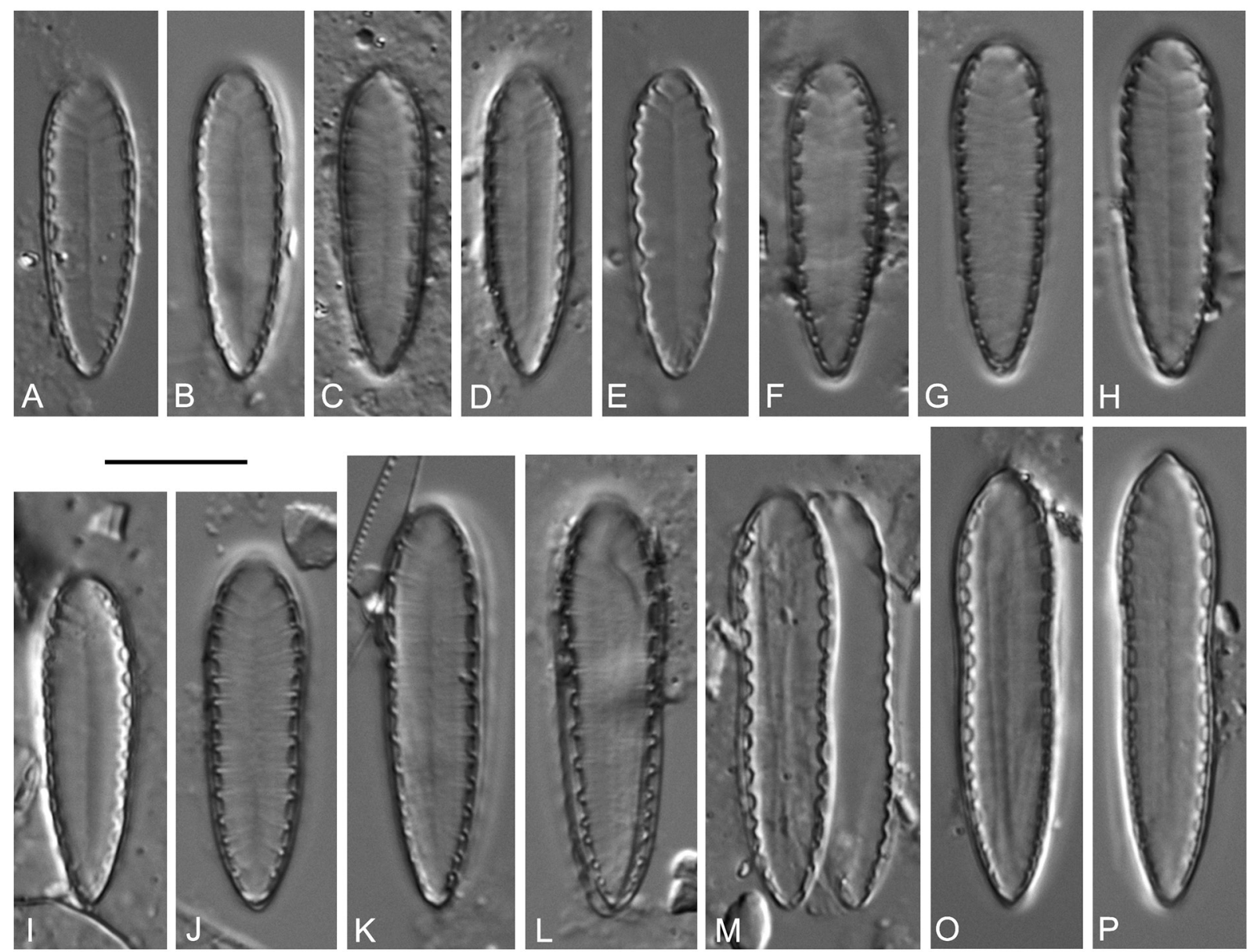

Fig. 6. Surirella congolensis sp. nov., from the holotype slide BR 4399, Lomami River, DR Congo, LM (DIC), valve views. G. Valve representing the holotype. Scale bar $=10 \mu \mathrm{m}$.
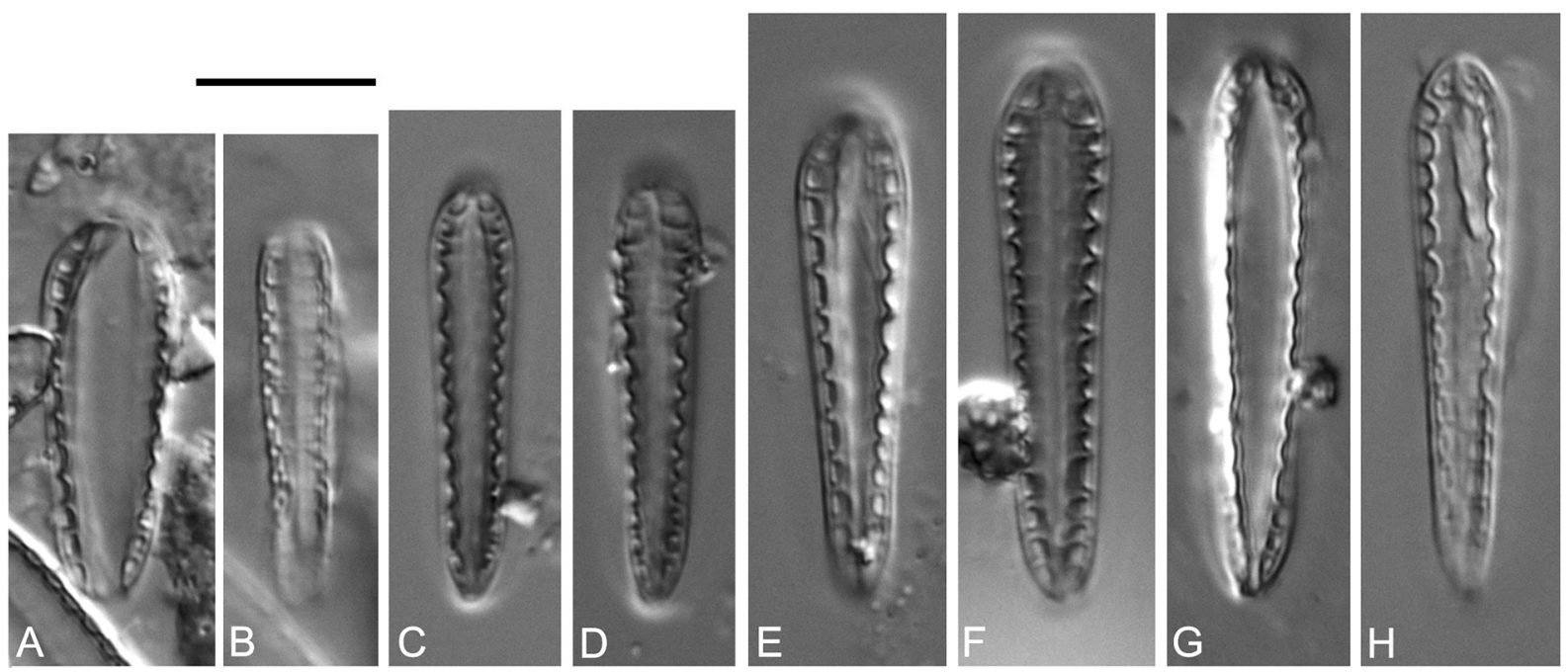

Fig. 7. Surirella congolensis sp. nov., from the holotype slide BR 4399, Lomami River, DR Congo, LM (DIC), girdle views. Scale bar $=10 \mu \mathrm{m}$. 

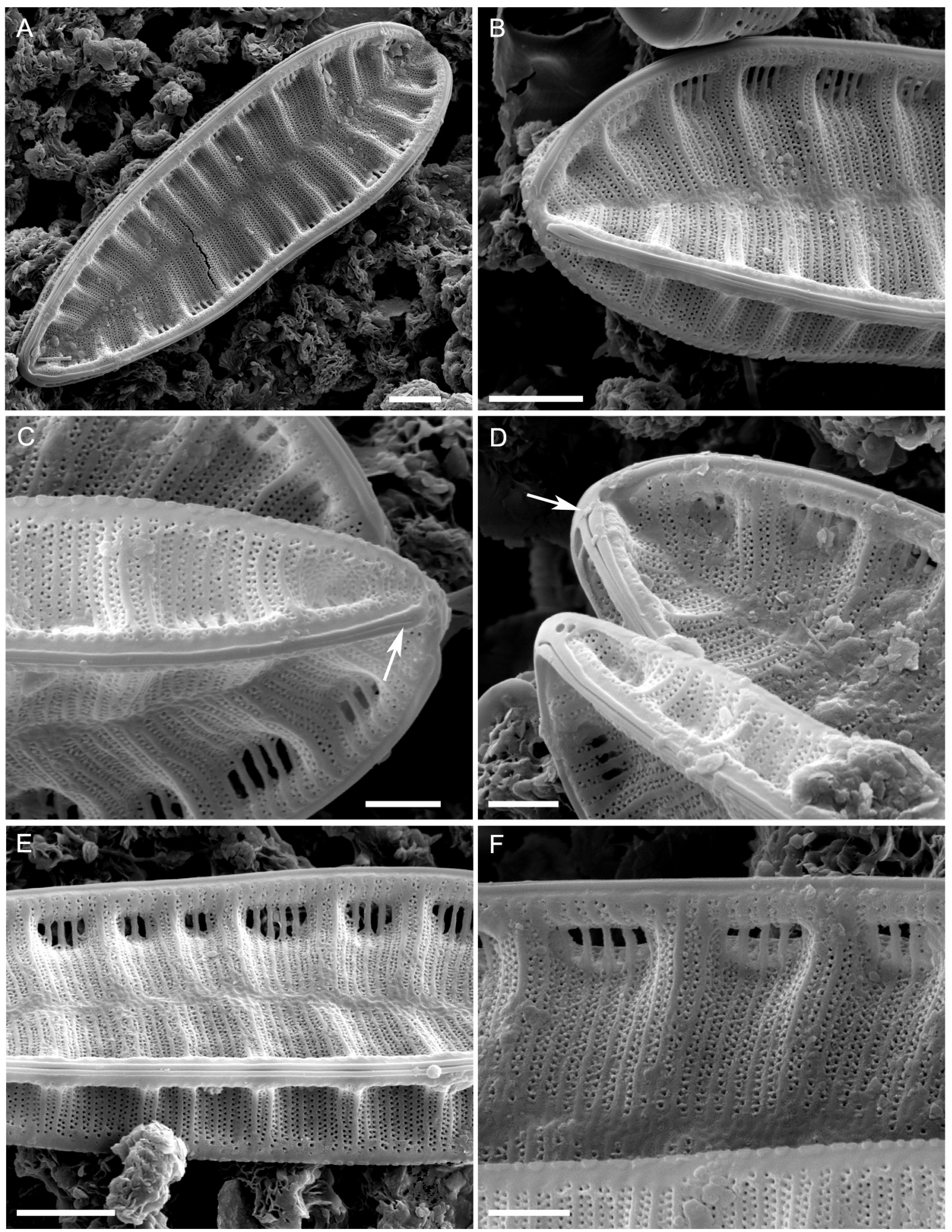

Fig. 8. Surirella congolensis sp. nov., type material from sample CCA 2071, Lomami River, DR Congo, SEM. External view. A. Overview. B-C. Detail of foot pole showing the straight not expanded raphe endings (arrow). D. Detail of the apical pole showing the slightly curved raphe endings (arrow). E-F. Detail of the biseriate striae and the open fenestrae with the fenestral bars. Scale bars: A-B $=2 \mu \mathrm{m} ; \mathrm{C}-\mathrm{F}=1 \mu \mathrm{m}$. 

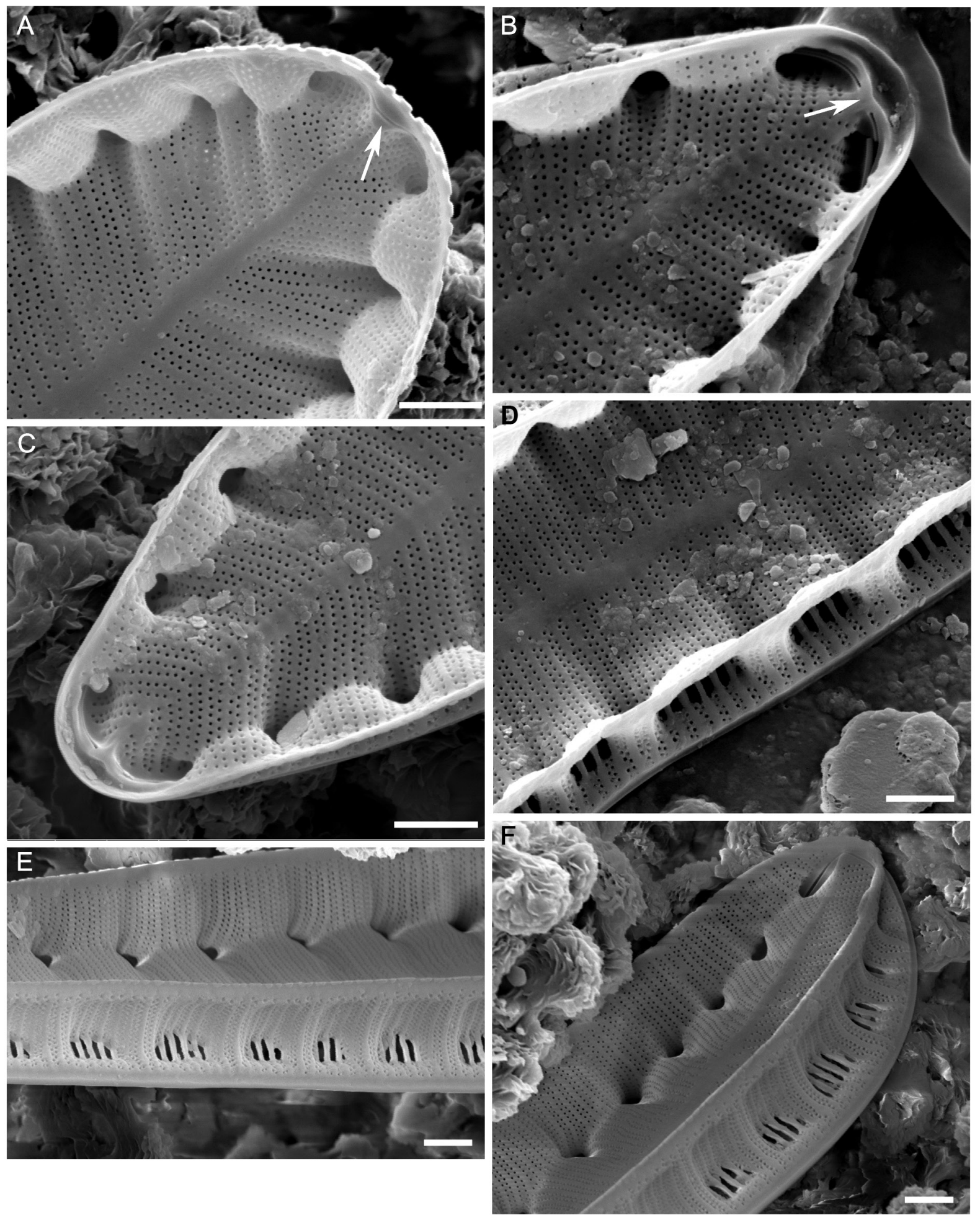

Fig. 9. Surirella congolensis sp. nov., type material from sample CCA 2071, Lomami River, DR Congo, SEM. Internal view. A-B. Head pole showing the continuous raphe (arrow). C-D. Foot pole showing the interruption of the raphe and the straight slightly expanded terminal raphe endings. $\mathbf{E}-\mathbf{F}$. Detail of the alar canals. Scale bars: $\mathrm{B}-\mathrm{C}=2 \mu \mathrm{m} ; \mathrm{A}, \mathrm{D}=1 \mu \mathrm{m}$. 


\section{Morphological observations on scanning electron microscopy (Figs 8-9)}

\section{External view}

Axial area narrow. Striae biseriate, continuing on the keel also above the fenestrae and on the mantle side. Raphe endings near the apical pole straight not enlarged (Fig. 8B-C), near the base pole straight and slightly bent towards the valve face (Fig. 8D). Striae composed of round areolae, in $10 \mu \mathrm{m}$, biseriate and continuing on the raphe sternum. Fenestrae open and divided by fenestral bars, openings between the fenestral bars located in the prolongation of the striae. No ornamentation such as spines or silica granules present on the valve face, except for silica plaques present at the edge of the valve mantle at the place where the valvocopula is attached to the valve (Fig. 8E).

\section{Internal view}

Raphe continuous on the apical pole (Fig. 9A) and interrupted near the foot pole with straight and slightly expanded raphe endings (Fig. 9B-C).

Girdle composed of several open, unornamented bands.

\section{Ecology}

Physical and chemical parameters measured at the type locality are as follows: temperature $25.7^{\circ} \mathrm{C}$, pH 6.06, conductivity $22.2 \mu \mathrm{S} \mathrm{cm}^{-1}, 0.060 \mathrm{mg} \mathrm{l}^{-1} \mathrm{NH}_{4}, 0.005 \mathrm{mg} \mathrm{l}^{-1} \mathrm{NO}_{2}, 0.446 \mathrm{mg} \mathrm{l}^{-1} \mathrm{NO}_{3}, 0.086 \mathrm{mg} \mathrm{l}^{-1}$ soluble reactive phosphorous (SRP).

Surirella congolensis sp. nov. was observed in a diatom community dominated by Navicula feuerbornii var. africana Foged, Gomphonema brasiliense subsp. pacificum Gerd Moser, Lange-Bertalot \& Metzeltin, Orthoseira roeseana (Rabenhorst) O'Meara, Eolimna spp. and Eunotia spp.

\section{Discussion}

Surirella ebalensis sp. nov. resembles S. agonaensis Foged described from Ghana in West Africa (Foged 1966; Cocquyt \& Kusber 2010). The shapes of the valves differ slightly, but the valve width is distinctly narrower in $S$. ebalensis sp. nov. (16.1-19.4 $\mu \mathrm{m})$ compared to the broader $S$. agonaensis $(27.5-30.0 \mu \mathrm{m})$. The valve length also is smaller: $40.3-64.4$ versus $78-80 \mu \mathrm{m}$, respectively. The alar canals are denser in Surirella ebalensis sp. nov. than in S. agonaensis: 2.2-3.0 compared to 1.4-1.6. Moreover, the wing projection is very distinct in the new species compared to the slightly distinct projection in S. agonaensis. Besides these differences observed in LM, the SEM study of S. ebalensis sp. nov. showed the presence of draped, often forked silica spine-like structures extending on the keel at the mantle side partially covering the fenestrae (Fig. 3C), these structures are absent in S. agonaensis (Cocquyt \& Kusber 2010). The spines of variable length on the top of the porcae (Fig. 4A-B) as present in S. ebalensis sp. nov., have not until now been observed in $S$. agonaensis, where silica granules are the only ornamentation on the valve face.

The closely related S. bonsaensis Foged, also decribed from Ghana in West Africa (Foged 1966; Cocquyt \& Kusber 2010) differs in valve shape, which is broadly linear and isopolar, and in larger valve dimensions (length 70-80 $\mu \mathrm{m}$, width $24.5-26.0 \mu \mathrm{m}$ ). There exists a small overlap in number of alar canals in $10 \mu \mathrm{m}: 2.2-3.0$ in S. ebalensis sp. nov. and 2.0-2.4 in S. bonsaensis. As in S. agonaensis the wing projection in $S$. bonsaensis is also less pronounced than the distinct projection in S. ebalensis sp. nov.. Moreover the striation is coarser (25 in $10 \mu \mathrm{m}$ in $S$. bonsaensis, 30 in $10 \mu \mathrm{m}$ in S. ebalensis sp. nov.) and in LM no spines or other ornamentation of the valve face is visible.

A third taxon described from Ghana, Surirella esamangensis Foged (Foged 1966; Cocquyt \& Kusber 2010 ), is also closely related to the new species described here. Some overlap exists in valve length (58.5-64.0 $\mu \mathrm{m}$ versus $40.3-64.5 \mu \mathrm{m})$, density of alar canals $(2.0-2.4$ in $10 \mu \mathrm{m}$ versus $2.2-3.0$ in $10 \mu \mathrm{m})$ and striae density (25-30 in $10 \mu \mathrm{m}$ versus 30 in $10 \mu \mathrm{m})$ but not in valve width $(22.5-24.0 \mu \mathrm{m}$ versus 
16.1-19.4 $\mu \mathrm{m})$. Moreover, in $S$. esamangensis the valve shape is elliptic and slightly heteropolar with evenly rounded apical and base pole and a relatively indistinct wing projection.

Spines on the keel in other Surirella taxa were also observed in material from Sulawesi (Bramburger et al. 2006), e.g., Surirella alata Hustedt, S. fimbriata Hustedt and S. tubicola Bramburger \& Hamilton. These spines are of different length than in the Congo material studied, but the spines in our material are often much larger. In the Sulawesi material spines were also observed on the valve face, for example in S. tenacis Bramburger \& Hamilton. Both are hollow structures, different from the flat full spines found in for example S. nervosa (A.W.F. Schmidt) Mayer. Some of the spine-like structures present on the valve face resemble the four spines present on the valve face of $S$. quadridentis Bramburger \& Hamilton. However, these four spines of $S$. quadridentis resemble more the spine-like structures of Cymatopleura calcarata Hustedt: also hollow structures (Cocquyt 2001) which are probably processes and not true spines. More studies, including internal valve views and cell wall ontogeny are needed to understand these spine-like structures.

Surirella congolensis sp. nov. is closely related to S. takoradiensis Foged, described from Ghana in West Africa (Foged 1966; Cocquyt \& Kusber 2010). Although both taxa are heteropolar and about the same length (18.7-33.0 compared to 20.0-27.0 (38.0) $\mu \mathrm{m}$ for $S$. takoradiensis) the valve shape differs: lanceolate in $S$. congolensis sp. nov. while ovate to oval-elliptical in $S$. takoradiensis, slightly constricted in the larger valves compared to no constriction at all, subarcuate compared to rounded base pole. Valves are narrower in $S$. congolensis sp. nov. $(5.5-6.9 \mu \mathrm{m}$, seldom up to $7.9 \mu \mathrm{m})$ than in $S$. takoradiensis (7.0-9.0 (10.5) $\mu \mathrm{m})$, and the alar canals in $10 \mu \mathrm{m}$ are mostly denser, 5.5-6.0 and 4.0-6.0, respectively. The fenestrae are lower in S. congolensis sp. nov. than in S. takoradiensis where the fenestrae are almost rectangular in girdle view.

Surirella congolensis sp. nov. is also related to Surirella pseudotenuissima Leclercq, described from Sumatra by Leclercq (1983) using material of the Friedrich Hustedt Diatom Collection (BRM X4/75, picture of the type in Hustedt 1938, tab. 43, fig. 8). Although S. pseudotenuissima is a tropical species it was reported from temperate regions in Europe (Belgium) by Denys (1985). It is a heteropolar species with a similar valve length of $25.0-57.0 \mu \mathrm{m}$, but much broader with a width of $9.5-13 \mu \mathrm{m}$. The alar canals (3.4-5.0 in $10 \mu \mathrm{m}$ compared to 5.5-6.0 in $10 \mu \mathrm{m}$ in S. congolensis sp. nov.) as well as the striae (23-26 striae in $10 \mu \mathrm{m}$ compared to about 30 in $10 \mu \mathrm{m}$ in $S$. congolensis sp. nov.) are coarser. The new taxon is also related to Surirella tenuissima Hustedt which has heteropolar valves with a length of $17.0-38.0 \mu \mathrm{m}$, a width of 6.0-11.0 $\mu \mathrm{m}$ and 4.0-7.0 alar canals in $10 \mu \mathrm{m}$, which are smaller than the fenestrae (Hustedt in Huber-Pestalozzi 1942). Surirella tenuissima is a littoral species reported from South America and Indo-Malaysia. In Sulawesi and the Philippines (Leyte) it was also found in the plankton (Hustedt in Huber-Pestalozzi 1942).

\section{Acknowledgements}

The first author is grateful to the Belgian Federal Science policy who funded the COBAFISH project $(\mathrm{SD} / \mathrm{AR} / 05 \mathrm{~A})$ in which the present study was undertaken. J.C. Taylor is a beneficiary of a mobility grant from the Marie Curie Actions of the European commission co-financed by the Belgian Federal Science Policy. J.C. Taylor is the recipient of South African National Research Foundation (NRF) incentive funding. Any opinions, findings and conclusions or recommendations expressed in this material are those of the author(s) and therefore the NRF does not accept any liability in regard thereto. Part of the material studied was sampled during the Boyekoli Ebale Congo 2010 expedition, organized by the Congo 2010 Consortium (composed of the University of Kisangani, the Royal Museum for Central Africa, the Royal Belgian Institute of Natural Sciences and the National Botanic Garden of Belgium) and funded by the Belgian Development Aid, the Belgian Science Policy and the Belgian Lottery. The authors are grateful to François Darchambeau and Ernest Tambwe and the other members of the COBAFISH field expedition in 2012 for sampling and measuring the physical and chemical parameters. 


\section{References}

Bramburger A.J., Haffner G.D., Hamilton P.B., Hinz F. \& Hehanussa P.E. 2006. An examination of species within the genus Surirella from the Malili lakes, Sulawesi Island, Indonesia, with description of 11 new taxa. Diatom Research 21 (1): 1-56. http://dx.doi.org/10.1080/0269249X.2006.9705650

Cocquyt C. 2001. Notes on Cymatopleura calcarata Hustedt (Bacillariophyceae), an endemic diatom from Lake Tanganyika. In: Jahn R. (ed.) Lange-Bertalot-Festschrift: Studies on Diatoms dedicated to Prof. Dr. h.c. Horst Lange-Bertalot on the occasion of his 65th birthday: 177-186. A.R.G. Gantner Verlag, Ruggell.

Cocquyt C. \& Kusber W.-H. 2010. Reinvestigation of West African Surirellaceae (Bacillariophyta) described by Foged from Ghana. Nova Hedwigia 91 (1-2): 111-136. http://dx.doi.org/10.1127/0029$\underline{5035 / 2010 / 0091-0111}$

Cocquyt C., de Haan M. \& Taylor J.C. 2013. Cavinula lilandae (Bacillariophyta), a new diatom species from the Congo Basin. Diatom Research 28 (2): 157-163. http://dx.doi.org/10.1080/026924 $\underline{9 X .2012 .753952}$

Compère P. 1995. Gomphonema zairense sp. nov. from the Tshopo waterfalls (Kisangani, Zaïre). Diatom Research 10 (1): 31-37. http://dx.doi.org/10.1080/0269249X.1995.9705328

Compère P., Lomema T. \& Omalokoho T. 1989. Stauroneis zairensis sp. nov. d'un étang de pisciculture à Kinshasa, Zaire. Diatom Research 4 (2): 217-225. http://dx.doi.org/10.1080/0269249X.1989.9705071

Compère P. \& Symoens J.-J. 1987. Region 7. Zaïre Basin-Bassin du Zaïre. In: Burgis M.J. \& Symoens J.-J. (eds) African wetlands and shallow water bodies-Zones humides et lacs peu profonds d'Afrique. Directory-Répertoire: 401-456. Editions de l'ORSTOM, Paris.

Compère P. \& Symoens J.-J. 1988. Region 7. Zaïre Basin-Bassin du Zaïre. In: Davies B. \& Gasse F. (eds) African wetlands and shallow water bodies-Zones humides et lacs peu profonds d'Afrique. Bibliography-Bibliographie: 289-337. Editions de l'ORSTOM, Paris.

Denys L. 1985. Diatoms from the "Groot \& Klein Schietveld" at Brasschaat (Northern Campine, Belgium). Bulletin de la Société royale de botanique de Belgique 118 (1): 29-40.

Duvigneaud P. \& Symoens J.-J. 1949. Observations sur la strate algale des formations herbeuses du sud du Congo belge. Lejeunia 13: 67-98.

Foged N. 1966. Freshwater diatoms from Ghana. Det Kongelige Danske Videnskarbernes Selskab: Biologiske Skrifter 15, Munksgaard, Copenhagen.

Golama Swana Kaketa A. 1992. Bacillariophycées, desmidiées et euglénophycées de la région de Kisangani (Zaïre). PhD thesis, Vrije Universiteit Brussel, Brussels, Belgium.

Golama Swana Kaketa A. 1996. Bacillariophycées, desmidiées et euglénophycées de la région de Kisangani (Zaïre). Classe des Sciences naturelles et médicales, Mémoires, Nouvelle Série 23 (3), Académie Royale des Sciences d'Outre-Mer, Brussels.

Huber-Pestalozzi G. 1942. Das Phytoplankton des Süsswassers: Systematik und Biologie. Vol. 2. Part. 2. Diatomeen. Die Binnengewässer 16, Schweizertbart'scher Verlag, Stuttgart.

Hustedt F. 1938. Systematische und ökologische Untersuchungen über die Diatomeen-Flora von Java, Bali und Sumatra. Archiv für Hydrobiologie, Supplement 15: 393-506.

Kufferath H. 1956a. Algues et protistes du fleuve Congo au large de l'île de Mateba. In: Expédition océanographique belge dans les eaux côtières africaines de l'Atlantique Sud (1948-1949). Résultats scientifiques. Vol. 5. Algues et protistes du fleuve Congo dans le Bas-Congo et de son estuaire (1): 1-25. Institut royal des sciences naturelles de Belgique, Brussels. 
Kufferath H. 1956b. Algues et protistes prélevés au large et dans la crique de Banana In: Expédition océanographique belge dans les eaux côtières africaines de l'Atlantique Sud (1948-1949). Résultats scientifiques. Vol. 5. Algues et protistes du fleuve Congo dans le Bas-Congo et de son estuaire (2): 33-37. Institut royal des sciences naturelles de Belgique, Brussels.

Kützing F.T. 1844. Die Kieselschaligen Bacillarien oder Diatomeen. Förstemann, Nordhausen. http:// dx.doi.org/10.5962/bhl.title. 64360

Leclercq L. 1983. Description et écologie de nouveaux taxons de diatomées des genres Surirella et Achnanthes. Bulletin du Jardin Botanique National de Belgique 53 (3-4): 491-505. http://dx.doi. org $/ 10.2307 / 3667805$

Medlin L. \& Kaczmarska I. 2004. Evolution of the diatoms: V. Morphological and cytological support for the major clades and a taxonomic revision. Phycologia 43 (3): 245-270. http://dx.doi.org/10.2216/ i0031-8884-43-3-245.1

Nagy Z.T., Kusamba Z.C., Tungaluma G.G., Lokasola A.L., Kolby J. \& Kielgast J. 2011. Foraging acrobatics of Toxicodryas blandingii in the Democratic Republic of the Congo. Hertpetology Notes 4: 91-92.

Round F.E., Crawford R.M. \& Mann D.G. 1990. The diatoms. Biology and morphology of the genera. Cambridge University Press, Cambridge.

Turpin P.J.F.1828. Observations sur le nouveau genre Surirella. Mémoires du Muséum d'Histoire naturelle 16: 361-368.

Virgilio M., Backeljau T., Emeleme R., Juakali J.L. \& De Meyer M. 2011. A quantitative comparison of frugivorous tephritids (Diptera: Tephritidae) in tropical forests and rural areas of the Democratic Republic of Congo. Bulletin of Entolomogical Research 101 (5): 591-597. http://dx.doi.org/10.1017/ $\underline{\mathrm{S} 0007485311000216}$

Manuscript received: 4 March 2015

Manuscript accepted: 9 June 2015

Published on: 17 August 2015

Topic editor: Thomas Janssen

Desk editor: Charlotte Thionois

Printed versions of all papers are also deposited in the libraries of the institutes that are members of the EJT consortium: Muséum national d'Histoire naturelle, Paris, France; Botanic Garden Meise, Belgium; Royal Museum for Central Africa, Tervuren, Belgium; Natural History Museum, London, United Kingdom; Royal Belgian Institute of Natural Sciences, Brussels, Belgium; Natural History Museum of Denmark, Copenhagen, Denmark. 